\title{
Genetic parameters of production traits of Hungarian Pig populations evaluated in separate and joint (field and station) tests
}

\begin{abstract}
Summary
Genetic parameters for various backfat measurements (BF1FT, BF2FT, BF3FT, BF1ST, BF2ST, BF3ST), average backfat thickness (ABFFT), loin muscle area (LMAFT), fat depth between the $3^{\text {rd }}$ and $4^{\text {th }}$ lumbar vertebrae (SF1FT), fat depth between the $3^{\text {rd }}$ and $4^{\text {th }}$ ribs (SF2FT), lean meat percentage (LMPFT) were estimated. The analysis was based on the national database of the field and station tests, using animal model in Hungarian Large White (LW), Hungarian Landrace (LR) breeds, and A-line of the Ka-Hyb hybrid (MLW) between May 1996 - February 2001. Heritability for BFFT traits ranged between 0.15-0.35. Similar interval was received for ABFFT (0.20-0.36) but reasonably higher estimates were observed in BFST traits (0.41-0.75). SFFT heritabilies (0.18-0.37) were close to those of BFFT traits while somewhat higher values were found in LMPFT (0.26-0.45) and LMAFT (0.31-0.58). Genetic correlations were generally positive among all fat depth measurements and negative with LMPFT. Genetic correlations between LMAFT-LMPFT were positive but contradictory results were found between LMAFT and fat depth measurements. The genetic correlations between BFFT traits and their station test counterparts (BFST) varied between 0.12-0.64.
\end{abstract}

Key Words: swine, genetic parameters, backfat depth, lean meat percentage

\section{Zusammenfassung}

Titel der Arbeit: Genetische Parameter von Produktionsmerkmalen ungarischer Schweinepopulationen, die unter Stations- und Feldbedingungen geprüft wurden

Es wurden genetische Parameter der an verschiedenen Stellen gemessenen Rückenspeckdicken (BF1FT, BF2FT, BF3FT, BF1ST, BF2ST, BF3ST), der durchschnittlichen Speckdicke (ABFFT), der Kotelettfläche (LMAFT), der Speckdicke zwischen den 3. und 4. Lendenwirbeln (SF1FT), der Speckdicke zwischen der 3. und 4. Rippe (SF2FT) und des Muskelfleischanteils (LMPFT) geschätzt. Die Analyse erfolgte mit Daten ungarischer Feldund Stationsprüfungen, zwischen Mai 1996 und Februar 2001, mit Hilfe eines Tiermodells an Tieren der Ungarischen Landrasse, dem Ungarischen Edelschwein und der KAHYB-A Linie. Die Heritabilitätswerte von BFFT-Eigenschaften lagen zwischen 0,15-0,35. Gleiche Werte wurden für ABFTT $(0,20-0,36)$ geschätzt. Bei den BFST-Messpunkten waren diese Werte eindeutig höher $(0,41-0,75)$. Die $h^{2}$-Werte für SFFT $(0,18-0,37)$ waren ähnlich wie bei den BFFT-Werten, für LMPFT und LMAFT wurden höhere Werte (0,26-0,45, bzw. 0,31$0,58)$ geschätzt. Die genetischen Korrelationen unter allen gemessenen Rückenspeck-dicken waren eindeutig positiv, aber mit LMPFT negativ. Die Korrelationswerte zwischen LMAFT und LMPFT waren positiv, aber zwischen Speckdicken und LMAFT wurden negative Werte ermittelt. Die genetischen Korrelationswerte lagen zwischen den BFFT und den in Stationsprüfung gemessenen gleichen Eigenschaften (BFST) zwischen 0,120,64 .

Schlüsselwörter: Schweine, genetische Parameter, Speckdicke, Muskelfleischanteil

\section{Introduction}

In recent years, the basic goal in animal production has been to establish herds that will meet consumer preference for lean meat (MORUPPA et al., 1990). Pig breeding is no exception as a $70 \mathrm{~kg}$ swine carcass may contain $31-37 \%$ fat. The waste fat can be trimmed from the carcasses but this process results in an increased labour cost which is eventually passed on to the consumer. Beside other factors (like restricted feeding) the 
solution for reducing fat includes genetic selection, and once genetic improvement is attained it is permanent (EISEN, 1989). Genetic selection therefore should target body composition traits like lean meat percentage, loin muscle area and backfat thickness. The latter can easily be recorded on live pigs using ultrasonic scanning equipment (WILSON, 1992) and has a good predictive value for assessing body composition. It is worth mentioning that ultrasonic scanning was first tested in the Hungarian pig breeding almost 30 years ago (SZABÓ et al., 1973).

In Hungary selection in pig breeding is based on data from field and station tests respectively. In the field test backfat shoulder, backfat mid-back, backfat loin, thickness measurements are taken on live animals using ultrasound scanning. By scanning the fat depth between the $3^{\text {rd }}$ and $4^{\text {th }}$ lumbar vertebrae, the fat depth between the $3^{\text {rd }}$ and $4^{\text {th }}$ ribs and the loin muscle area it is also possible to estimate the lean meat percentage on live pigs. In Hungary application of the latter process is compulsory since 1998. Using these basic measurements two further traits are being calculated, namely average backfat thickness and lean meat percentage. These calculated traits are involved in the field test scores on which selection is partially based.

Concerning the station test, after the test animals are slaughtered fat thickness values are measured on the carcasses at the same regions as in the field test. From a genetic viewpoint a certain trait measured in two environments (in this case field and station tests) can be regarded as two separate traits. The genetic correlation coefficient among the two traits provides the genotype environment interaction (FALCONER, 1952). Genetic correlation close to unity (higher than 0.8 ) would mean the same ranking of genotypes in both environments. On the other hand a low genetic correlation for a certain trait measured in the field and station tests would mean that the ranking of boars based on own performance test (field test) and progeny test (station test) would differ significantly.

By the present study the authors had two goals in mind. The first was to estimate the genetic parameters of all the scanned and calculated traits (field test) using the data of Hungarian Large White and Hungarian Landrace populations, and one synthethic Large White type line (the A-line) of the Ka-Hyb hybrid pig breeding program. Thus it will be clear whether or not the heritabilities and genetic correlation coefficients make a reasonable genetic gain possible, as far as body composition is concerned. The second objective was to test the existence of the genotype environment interaction by estimating the genetic correlation coefficients between the same backfat measurements (shoulder, mid-back, loin) in the field and station tests respectively as they will show the reliability of the ultrasonic field test data which is collected at high costs.

\section{Material and Methods}

\section{Data recording}

The genetic analysis was conducted on the data collected by the National Institute for Agricultural Quality Control of Hungary between May 1996 - February 2001, in the course of the field and station tests respectively. Hungarian Large White (LW), Hungarian Landrace breeds (LR), and one synthetic Large White type line (the A-line) of the Ka-Hyb hybrid pig breeding program (MLW) were analysed.

Field test (own performance test)

As reported by GROENEVELD et al. (1996) in the field test three ultrasonic (SONOMARK 100) backfat measurements are taken from boars and gilts between 80 
and 110kg at the middle of the spinal chord (shoulder: BF1FT, mid-back: BF2FT, loin: BF3FT). Average backfat thickness (ABFFT) is calculated as the average of these three measurements. Since 1998 fat depth between the $3^{\text {rd }}$ and $4^{\text {th }}$ lumbar vertebrae (SF1FT) (8cm laterally from the spinal chord), fat depth between the $3^{\text {rd }}$ and $4^{\text {th }}$ ribs (SF2FT) (6cm laterally from the spinal chord) and the loin muscle area between the $3^{\text {rd }}$ and $4^{\text {th }}$ ribs (LMAFT) (6cm laterally from the spinal chord) are also recorded using ultrasonic scanning equipment. Using SF1FT, SF2FT, LMAFT measurements lean meat percentage (LMPFT) is also calculated. Body weight is recorded at the same time with an accuracy of $1 \mathrm{~kg}$. All healthy animals in a litter are tested on the farm except for those sent to the station. Gilts are kept in groups up to 25 pigs while boars are raised in smaller groups up to 15 on an ad libitum feeding regime.

Table 1

Basic statistics for the examined traits (Statistische Daten der analysierten Merkmale)

\begin{tabular}{|c|c|c|c|c|c|}
\hline Traits $^{\mathrm{a}}$ & Breed $^{b}$ & Type of test ${ }^{C}$ & No. records ${ }^{d}$ & Mean ${ }^{\mathrm{e}}$ & $\sigma$ \\
\hline \multirow[t]{3}{*}{ BF1FT (mm) } & $\overline{L W}$ & field & 67422 & 26.24 & 2.97 \\
\hline & LR & field & 33079 & 25.85 & 3.05 \\
\hline & MLW & field & 4071 & 26.77 & 2.47 \\
\hline \multirow[t]{3}{*}{$\mathrm{BF} 2 \mathrm{FT}(\mathrm{mm})$} & LW & field & 67422 & 14.26 & 1.95 \\
\hline & LR & field & 33079 & 13.36 & 2.01 \\
\hline & MLW & field & 4071 & 13.93 & 1.64 \\
\hline \multirow[t]{3}{*}{ BF3FT (mm) } & LW & field & 67422 & 15.35 & 2.23 \\
\hline & LR & field & 33079 & 15.05 & 1.85 \\
\hline & MLW & field & 4071 & 16.99 & 2.13 \\
\hline \multirow[t]{3}{*}{ ABFFT (mm) } & LW & field & 67422 & 18.61 & 1.92 \\
\hline & LR & field & 33079 & 18.08 & 1.87 \\
\hline & MLW & field & 4071 & 19.23 & 1.87 \\
\hline \multirow[t]{3}{*}{ SF1FT $(\mathrm{mm})$} & $\mathrm{LW}$ & field & 6591 & 14.43 & 2.87 \\
\hline & LR & field & 4878 & 13.40 & 3.23 \\
\hline & MLW & field & 301 & 14.87 & 1.79 \\
\hline \multirow[t]{3}{*}{$\mathrm{SF} 2 \mathrm{FT}(\mathrm{mm})$} & LW & field & 6591 & 12.35 & 2.54 \\
\hline & LR & field & 4878 & 11.57 & 2.96 \\
\hline & MLW & field & 301 & 10.92 & 1.93 \\
\hline \multirow[t]{3}{*}{ LMAFT $\left(\mathrm{cm}^{2}\right)$} & LW & field & 6591 & 44.59 & 6.76 \\
\hline & LR & field & 4878 & 43.29 & 7.37 \\
\hline & MLW & field & 301 & 43.54 & 8.06 \\
\hline \multirow[t]{3}{*}{ LMPFT (\%) } & LW & field & 6591 & 56.43 & 2.05 \\
\hline & LR & field & 4878 & 56.75 & 2.02 \\
\hline & MLW & field & 301 & 57.03 & 2.10 \\
\hline \multirow[t]{3}{*}{ BF1ST (mm) } & LW & station & 6855 & 34.89 & 6.23 \\
\hline & LR & station & 2791 & 32.38 & 6.29 \\
\hline & MLW & station & 786 & 33.59 & 5.86 \\
\hline \multirow[t]{3}{*}{ BF2ST (mm) } & LW & station & 6855 & 18.88 & 4.28 \\
\hline & LR & station & 2791 & 18.06 & 4.59 \\
\hline & MLW & station & 786 & 19.31 & 4.45 \\
\hline \multirow[t]{3}{*}{ BF3ST (mm) } & LW & station & 6855 & 18.81 & 4.98 \\
\hline & LR & station & 2791 & 17.34 & 4.97 \\
\hline & MLW & station & 786 & 17.56 & 5.37 \\
\hline
\end{tabular}

${ }^{\mathrm{a}}$ Merkmale; ${ }^{\mathrm{b}}$ Rasse; ${ }^{\mathrm{C}}$ Testtyp; ${ }^{\mathrm{d}}$ Datensatz; ${ }^{\mathrm{e}}$ Mittelwert

\section{Station test (progeny test)}

Concerning the station test GROENEVELD et al. (1996) from one litter a castrate and a female are sent to the station between the age of 65-77 days. Body weight of the animals at the age of 65 days should be at least $17 \mathrm{~kg}$ but not greater than $32 \mathrm{~kg}$. After some preliminary adaptation period the test begins at the age of 80 days (body weight 
at this age is at least $23 \mathrm{~kg}$ ) and ends with reaching the final weight of $105 \mathrm{~kg}$. Body weight is measured at the beginning and at the end of the test with an accuracy of $1 \mathrm{~kg}$. Animals are fed ad libitum and penned individually. After slaughtering all animals are dissected and the same backfat thickness measurements (together with the skin) are taken as in the field test (shoulder: BF1ST, mid-back: BF2ST, loin: BF3ST) with an accuracy of $1 \mathrm{~mm}$ using a measuring rod. Basic statistics of the field and station test data can be seen in Table 1 .

Statistical analysis

The statistical analysis consisted of two consecutive steps. The first step was testing for the significance of the various environmental factors (fixed effects) conducting least squares analyses using the GLM procedure of the BMDP package (DIXON et al., 1988) leaving only significant factors in the model.

The second step was the estimation of the heritabilities of the individual traits and their genetic correlations. The method used to obtain the (co)variance components was the appropriate variation of the animal model using the PEST (for data coding) (GROENEVELD, 1990) and VCE 4 (GROENEVELD, 1998) softwares (under LINUX) based on the BLUP and REML methods.

The heritability estimates of BF1FT, BF2FT, BF3FT, ABFFT, SF1FT, SF2FT, LMAFT, LMPFT, BF1ST, BF2ST, BF3ST were obtained by using the following linear model:

$y=X b+Z a+e$

where (according to MRODE, 1996):

$\mathbf{y}=$ vector of observations, $\mathbf{b}=$ vector of fixed effects, $\mathbf{a}=$ vector of random animal effects, $\mathbf{e}=$ vector of random residual effects, $\mathbf{X}$ and $\mathbf{Z}$ are incidence matrices relating records to fixed and random animal effects, respectively.

Expected values of $\mathbf{a}$ and $\mathbf{e}$ were $\mathrm{E}(\mathbf{a})=\mathrm{E}(\mathbf{e})=0$. The variance-covariance structure assumed to be $\mathrm{V}(\mathbf{a})=A \sigma^{2} \mathrm{a}, \mathrm{V}(\mathbf{e})=\mathrm{I}^{2} \mathrm{e}$, and $\operatorname{cov}(\mathbf{a}, \mathbf{e})=\operatorname{Cov}(\mathbf{e}, \mathbf{a})=0$, where $\mathrm{A}$ is the numerator relationship matrix. Also $\operatorname{cov}(\mathbf{y}, \mathbf{a})=\mathrm{ZAI}^{2} \mathrm{a}$.

Regarding the fixed effects, in the field test, the herd, sex, and year-month (of the field test) effects significantly influenced all the examined traits. The effect of the weight of the animals was also taken into account in each trait by treating this factor as a covariate. In the station test traits fixed effects were herd, sex, and year-month (of the station test) and station. Due to the fact that the level of fostering was as high as 30\% litter effects were neglected both in the field and station tests and only animal effects were considered as random effects.

Distribution of $\mathbf{y}$ was assumed to be normal each trait was determined by many additive genes of infinitesimal effects at infinitely many unlinked loci. Genetic correlations were estimated among BF1FT, BF2FT, BF3FT, ABFFT, SF1FT, SF2FT, LMAFT, LMPFT, among BF1ST, BF2ST, BF3ST and between BF1FT-BF1ST, BF2FT-BF2ST, BF3FT-BF3ST. Due to the size of the datasets and the relatively low computing capacity (Intel Pentium $400 \mathrm{MHz}$ Pro, 128MB RAM) genetic correlations could only be estimated for two traits at a time. Structure of the field and station test data can be seen in Table 2 . 
Table 2

Structure of field and station test data (Stationstest und Feld Test Datensatz)

\begin{tabular}{|c|c|c|c|c|c|c|}
\hline Traits $^{\mathrm{a}}$ & Breed $^{b}$ & Herd $^{\mathrm{C}}$ & Sex ${ }^{d}$ & Year-monthe & Station ${ }^{\mathrm{f}}$ & Tot. pedigree \\
\hline \multirow[t]{3}{*}{$\overline{\text { BF1FT }}$} & LW & 68 & 2 & 57 & - & 77035 \\
\hline & LR & 62 & 2 & 58 & - & 39667 \\
\hline & MLW & 10 & 2 & 36 & - & 4758 \\
\hline \multirow{3}{*}{$\mathrm{BF} 2 \mathrm{FT}$} & LW & 68 & 2 & 57 & - & 77035 \\
\hline & LR & 62 & 2 & 58 & - & 39667 \\
\hline & MLW & 10 & 2 & 36 & - & 4758 \\
\hline \multirow[t]{3}{*}{ BF3FT } & LW & 68 & 2 & 57 & - & 77035 \\
\hline & LR & 62 & 2 & 58 & - & 39667 \\
\hline & MLW & 10 & 2 & 36 & - & 4758 \\
\hline \multirow[t]{3}{*}{ ABFFT } & LW & 68 & 2 & 57 & - & 77035 \\
\hline & LR & 62 & 2 & 58 & - & 39667 \\
\hline & MLW & 10 & 2 & 36 & - & 4758 \\
\hline \multirow[t]{3}{*}{ SF1FT } & LW & 31 & 2 & 31 & - & 77035 \\
\hline & LR & 22 & 2 & 44 & - & 39667 \\
\hline & MLW & 6 & 2 & 9 & - & 4758 \\
\hline \multirow[t]{3}{*}{ SF2FT } & LW & 31 & 2 & 31 & - & 77035 \\
\hline & LR & 22 & 2 & 44 & - & 39667 \\
\hline & MLW & 6 & 2 & 9 & - & 4758 \\
\hline \multirow{3}{*}{ LMAFT } & LW & 31 & 2 & 31 & - & 77035 \\
\hline & LR & 22 & 2 & 44 & - & 39667 \\
\hline & MLW & 6 & 2 & 9 & - & 4758 \\
\hline \multirow[t]{3}{*}{ LMPFT } & LW & 31 & 2 & 31 & - & 77035 \\
\hline & LR & 22 & 2 & 44 & - & 39667 \\
\hline & MLW & 6 & 2 & 9 & - & 4758 \\
\hline \multirow{3}{*}{ BF1ST } & LW & 57 & 2 & 59 & 7 & 84399 \\
\hline & LR & 34 & 2 & 56 & 7 & 42732 \\
\hline & MLW & 10 & 2 & 55 & 5 & 5633 \\
\hline \multirow[t]{3}{*}{ BF2ST } & LW & 57 & 2 & 59 & 7 & 84399 \\
\hline & LR & 34 & 2 & 56 & 7 & 42732 \\
\hline & MLW & 10 & 2 & 55 & 5 & 5633 \\
\hline \multirow[t]{3}{*}{ BF3ST } & LW & 57 & 2 & 59 & 7 & 84399 \\
\hline & LR & 34 & 2 & 56 & 7 & 42732 \\
\hline & MLW & 10 & 2 & 55 & 5 & 5633 \\
\hline
\end{tabular}

${ }^{\mathrm{a}}$ Merkmale; ${ }^{\mathrm{b}}$ Rasse; ${ }^{\mathrm{c}}$ Betrieb; ${ }^{\mathrm{d}}$ Geschlecht; ${ }^{\mathrm{e}}$ Jahr-Monat; ${ }^{\mathrm{f}}$ Station

\section{Results and Discussion}

Heritability estimates

Concerning the various BF (shoulder, mid-back, loin) traits differentiation should be made between the heritability estimates of the field and station tests respectively. Field test results showed generally low heritabilities (Table 3) regardless of the examined breeds. The MLW estimates were especially low, these results might be (at least partly) explained by the relatively small size of the analysed dataset. On the other hand heritabilities of the LW and LR were only slightly higher though the size of the analysed dataset was reasonable. As argued by TRAN et al. (1993) the results of the ultrasonic scanning can be severely biased which can easily be the reason for the low heritabilities. They argued that especially in case of the BF shoulder the possibility of taking biased measurements can be as high as $40 \%$. CSATÓ et al. (1990) tested the reliability of the ultrasonic BF measurements by scanning live animals then slaughtering them and measuring the carcasses of the same animals on the same regions. The correlations among the measurements were only moderate or low (0.100.56) which involves the possibility of an imprecise ultrasonic scanning. On the other 
hand MERKS (1988) found that the operator of the ultrasound equipment was responsible for only $5 \%$ of the total variation of the measured traits, which means that it is possible to obtain relatively high heritability estimates using this technique (i.e. the residual variance can be relatively low). Accordingly CAMERON (1993) received higher heritability estimates for BF shoulder (0.27-0.56), BF mid-back (0.48-0.60) and BF loin (0.48-0.54) in his selection experiment than those reported here using ultrasound scanning.

Station test heritabilities were much higher than that of the field test's. The estimates (Table 3) ranged between moderately high (shoulder, mid-back) and high (loin). The high values of the LR breed is worth mentioning. It seems that this breed is highly suitable for carcass measurements. Using Hungarian Large White and Duroc breeds VÁRADI et al. (1997) also analysed the data of various station tests conducted at Keszthely, Hungary. The heritabilities were very similar to those received here (0.5056 for shoulder, $0.47-0.55$ mid-back and $0.72-0.78$ for loin). Their results justify the well known fact that in general station tests are much more reliable than the field tests. ABFFT has been widely used as a selection criterion in order to improve body composition in pigs during the last decades. Due to the reason that this trait is calculated as the average of three $\mathrm{BF}$ measurements its error term is reduced artificially which results in a relatively high heritability (at least theoretically). Looking the results of 16 references reviewed by CLUTTER and BRASCAMP (1998) they found that the heritabilities for the ABF ranged between 0.12-0.74 and the average value was 0.49 which is moderately high. On the contrary results of the present study showed lower heritabilities (Table 3.). Nevertheless it has to be mentioned that using the national Hungarian dataset GROENEVELD et al. (1996) received even lower heritabilities (between 0.10-0.20) for ABF compared to the values reported by this study. Commenting on their results GROENEVELD et al. (1996) suggested that there might be some problems recording this trait. The same conclusion was also reached by TRAN et al. (1993) who also received very low $\mathrm{h}^{2}$ values (in two of the three investigated farms) for a trait like ABF $\left(\mathrm{h}^{2}\right.$ 0.04-0.28). Again it can be concluded that the field test can be considered less accurate than the station tests according to SELLIER (1998) heritability of BF was increased by some 30\% (0.36 vs. $0.49)$ comparing field vs. station tests.

Concerning SF1FT, SF2FT the heritabilities were similar to those of the various BFFT estimates. Unfortunately no relevant reference was found to compare the present results with. Nevertheless it can be stated that probably higher heritabilities were expected than those estimated here (Table 3.). Contrary to the other field test traits discussed hitherto LMAFT showed moderately high heritabilities especially in case of MLW. Somewhat lower heritabilities $\left(\mathrm{h}^{2} 0.24\right)$ were found by JOHNSON et al. (1999) for LMA using ultrasonic field test data on LW, meanwhile BERESKIN (1987) also analysed ultrasonic data but unlike the previous author (who used the animal model, REML) classical experimental designs were used for estimating the heritability, namely paternal half-sib families and parent-offspring regression analyses (boars on sires, boars on dams, boars on midparent, gilts on sires, gilts on dams, gilts on midparents). The estimates ranged between 0.13-0.35 which can be regarded as low (even though estimate of gilts on dams is biased with maternal effect). VÁRADI et al. (1997) on the other hand received moderately high (0.40-0.64) heritabilities but these values came from a station test. 
Unlike ABFFT the heritabilities of LMPFT (Table 3) were lower than those of its component's (SF1FT, SF2FT, LMAFT). One could have argued that a possible explanation of the received (relatively) low heritability was the small standard deviation of the measured trait (Table 1.). However KNAPP et al. (1997) analysed the genetic parameters of the lean meat percentage of the Large White Landrace and Pietrain breeds. The $h^{2}(0.53,0.43,0.40)$ showed that the lean meat percentage was a favourable trait regarding the possible genetic progress. The low standard deviation of lean meat percentages $(2.4,2.4,2.2)$ compared with their mean $(45.1,45.3,53.6)$ showed that the small cv\% of LMPFT alone could not be the reason of the relatively low heritabilities reported here. HOVENIER et al. (1992) also found high (0.63) heritability for the same trait. On the other hand using the same softwares (PEST, VCE) as the present authors very similar LMPFT heritability values were reported by GROENEVELD et al. (1998) for the Czech pig breeds on the national dataset $\left(\mathrm{h}^{2} 0.25\right.$ 0.36) to those in this report, though more recent estimates showed somewhat higher $\left(h^{2}\right.$ 0.42-0.54) values (WOLF et al., 2000; WOLF et al., 2001) for the Czech pig populations.

Table 3

Heritability estimates of the field, and station test traits. Standard errors of estimates are given in brackets (Schätzung der Stations- und Feldtestmerkmale (Standardabweichung in Klammern))

\begin{tabular}{cccc}
\hline Traits $^{\mathrm{a}}$ & $\mathrm{LW}^{\mathrm{b}}$ & $\mathrm{LR}^{\mathrm{C}}$ & $\mathrm{MLW}^{\mathrm{d}}$ \\
\hline BF1FT & $0.35(0.01)$ & $0.32(0.01)$ & $0.15(0.02)$ \\
BF2FT & $0.27(0.01)$ & $0.28(0.01)$ & $0.20(0.02)$ \\
BF3FT & $0.34(0.01)$ & $0.26(0.01)$ & $0.19(0.02)$ \\
ABFFT & $0.36(0.01)$ & $0.38(0.01)$ & $0.20(0.02)$ \\
SF1FT & $0.29(0.03)$ & $0.31(0.03)$ & $0.18(0.09)$ \\
SF2FT & $0.33(0.03)$ & $0.37(0.03)$ & $0.20(0.13)$ \\
LMAFT & $0.31(0.02)$ & $0.44(0.03)$ & $0.58(0.15)$ \\
LMPFT & $0.26(0.02)$ & $0.38(0.04)$ & $0.45(0.17)$ \\
BF1ST & $0.46(0.02)$ & $0.62(0.04)$ & $0.49(0.08)$ \\
BF2ST & $0.41(0.02)$ & $0.70(0.04)$ & $0.42(0.08)$ \\
BF3ST & $0.52(0.03)$ & $0.75(0.05)$ & $0.64(0.10)$ \\
\hline
\end{tabular}

${ }^{\mathrm{a}}$ Merkmale; ${ }^{\mathrm{b}}$ Ungarisches Edelschwein; ${ }^{\mathrm{C}}$ Ungarische Landrasse; ${ }^{\mathrm{d}}$ Eine synthetische Linie des Ka-Hyb Zuchtprogramms

Genetic correlation coefficients

Regarding the estimated genetic correlation coefficients among the field test traits (Table 4), the genetic correlation among the various fat depth estimates (both BFFT and SFFT) were generally positive except in MLW where some negative values were also found. However, as mentioned earlier the size of the analysed dataset was significantly smaller than in LW or LR and the standard errors of the estimates were considerably larger than in case of LW and LR. Looking at the various fat thickness in more detail it can be said that the genetic correlation coefficients among BFFT traits ranged between moderately high and very high except for LW where BF3FT showed low genetic correlation with BF1FT and BF2FT. This result cannot be explained at the moment and needs further examination. Regarding SF1FT and SF2FT they were moderately correlated but in MLW the same remark can be stated as above. ABFFT represents well all the three ultrasonic measurements taken on the spinal chord which explains why this trait was used as the main selection criterion trait for body 
composition during the past decades. Yet in Hungary (as in many other European countries) it will be replaced with LMPFT hence selection for body composition will be more direct than before since these traits are negatively correlated (as found by BIDANEL and DUCOS, 1996; DUCOS, 1994). On the other hand there was a moderately high and high genetic correlation between LMPFT and LMAFT. Similar

Table 4

Genetic correlation coefficient estimates of the field test traits. Standard errors of estimates are given in brackets (Genetische Korrelationen der Feldtestmerkmale (Standardabweichung in Klammern))

\begin{tabular}{|c|c|c|c|c|c|c|c|c|}
\hline Breed $^{\mathrm{a}}$ & $\mathrm{BF}^{2} \mathrm{FT}^{\mathrm{b}}$ & BF3FT $^{\mathrm{C}}$ & $\mathrm{ABFFT}^{\mathrm{d}}$ & SF1FT ${ }^{\mathrm{e}}$ & SF2FT $^{f}$ & LMAFTg & LMPFTh $^{\text {h }}$ & Traits ${ }^{\mathrm{i}}$ \\
\hline $\mathrm{LW}$ & $\begin{array}{c}0.69 \\
(0.02)\end{array}$ & $\begin{array}{c}0.24 \\
(0.02) \\
0.44 \\
(0.02)\end{array}$ & $\begin{array}{c}0.84 \\
(0.01) \\
0.87 \\
(0.01) \\
0.68 \\
(0.01)\end{array}$ & $\begin{array}{c}0.57 \\
(0.06) \\
0.95 \\
(0.07) \\
0.89 \\
(0.04) \\
0.96 \\
(0.04)\end{array}$ & $\begin{array}{c}0.71 \\
(0.05) \\
0.65 \\
(0.05) \\
0.12 \\
(0.07) \\
0.56 \\
(0.05) \\
0.46 \\
(0.09)\end{array}$ & $\begin{array}{c}0.68 \\
(0.06) \\
0.39 \\
(0.08) \\
0.02 \\
(0.10) \\
0.39 \\
(0.08) \\
0.07 \\
(0.13) \\
0.39 \\
(0.11)\end{array}$ & $\begin{array}{c}-0.29 \\
(0.08) \\
-0.52 \\
(0.08) \\
-0.21 \\
(0.09) \\
-0.46 \\
(0.08) \\
-0.52 \\
(0.10) \\
-0.74 \\
(0.06) \\
0.32 \\
(0.11)\end{array}$ & $\begin{array}{l}\text { BF1FT } \\
\text { BF2FT } \\
\text { BF3FT } \\
\text { ABFFT } \\
\text { SF1FT } \\
\text { SF2FT } \\
\text { LMAFT }\end{array}$ \\
\hline Breed & BF2FT & BF3FT & ABFFT & SF1FT & SF2FT & LMAFT & LMPFT & Traits \\
\hline LR & $\begin{array}{c}0.78 \\
(0.01)\end{array}$ & $\begin{array}{c}0.66 \\
(0.02) \\
0.75 \\
(0.01)\end{array}$ & $\begin{array}{c}0.92 \\
(0.01) \\
0.92 \\
(0.01) \\
0.87 \\
(0.01)\end{array}$ & $\begin{array}{c}0.56 \\
(0.05) \\
0.73 \\
(0.05) \\
0.76 \\
(0.04) \\
0.70 \\
(0.05)\end{array}$ & $\begin{array}{c}0.40 \\
(0.05) \\
(0.53 \\
(0.04)) \\
0.42 \\
(0.05) \\
0.45 \\
(0.04) \\
0.72 \\
(0.04)\end{array}$ & $\begin{array}{c}0.21 \\
(0.05) \\
0.24 \\
(0.05) \\
0.13 \\
(0.05) \\
0.21 \\
(0.04) \\
0.15 \\
(0.07) \\
0.29 \\
(0.06)\end{array}$ & $\begin{array}{c}-0.25 \\
(0.05) \\
-0.34 \\
(0.05) \\
-0.34 \\
(0.06) \\
-0.29 \\
(0.05) \\
-0.63 \\
(0.05) \\
-0.67 \\
(0.04) \\
0.51 \\
(0.05)\end{array}$ & $\begin{array}{l}\text { BF1FT } \\
\text { BF2FT } \\
\text { BF3FT } \\
\text { ABFFT } \\
\text { SF1FT } \\
\text { SF2FT } \\
\text { LMAFT }\end{array}$ \\
\hline BF1FT & BF2FT & BF3FT & ABFFT & SF1FT & SF2FT & LMAFT & LMPFT & Traits \\
\hline MLW & $\begin{array}{c}0.78 \\
(0.01)\end{array}$ & $\begin{array}{c}0.66 \\
(0.02) \\
0.75 \\
(0.01)\end{array}$ & $\begin{array}{c}0.92 \\
(0.01) \\
0.92 \\
(0.01) \\
0.87 \\
(0.01)\end{array}$ & $\begin{array}{c}0.56 \\
(0.05) \\
0.73 \\
(0.05) \\
0.76 \\
(0.04) \\
0.70 \\
(0.05)\end{array}$ & $\begin{array}{c}0.40 \\
(0.05) \\
(0.53 \\
(0.04)) \\
0.42 \\
(0.05) \\
0.45 \\
(0.04) \\
0.72 \\
(0.04)\end{array}$ & $\begin{array}{c}0.21 \\
(0.05) \\
0.24 \\
(0.05) \\
0.13 \\
(0.05) \\
0.21 \\
(0.04) \\
0.15 \\
(0.07) \\
0.29 \\
(0.06)\end{array}$ & $\begin{array}{c}-0.25 \\
(0.05) \\
-0.34 \\
(0.05) \\
-0.34 \\
(0.06) \\
-0.29 \\
(0.05) \\
-0.63 \\
(0.05) \\
-0.67 \\
(0.04) \\
0.51 \\
(0.05)\end{array}$ & $\begin{array}{l}\text { BF1FT } \\
\text { BF2FT } \\
\text { BF3FT } \\
\text { ABFFT } \\
\text { SF1FT } \\
\text { SF2FT } \\
\text { LMAFT }\end{array}$ \\
\hline
\end{tabular}


results were found by STEWART and SCHINKEL (1989) (rg 0.65). Concerning LMAFT and various fat depth measurements in our study generally positive values were found, on the contrary highly negative value was reported by BERESKIN (1987) meanwhile JOHNSON et al. (1999) found negative but low correlations which might suggest that the sign of the genetic correlation between these two traits depends on the analysed population.

Estimated genetic correlations among the three BF measurements of the station tests exceeded those of the field test's (Table 5.). Nevertheless in case of the MLW the genetic correlations were close to unity, these results should be treated with caution and probably were the consequence of the small dataset even though the standard errors were low.

Table 5

Genetic correlation coefficient estimates of the station test traits. Standard errors of estimates are given in brackets (Genetische Korrelationen der Stationstestmerkmale (Standardabweichung in Klammern))

\begin{tabular}{ccc|c}
\hline BF1ST $^{\mathrm{a}}-\mathrm{BF} 2 \mathrm{ST}^{\mathrm{b}}$ & BF1ST-BF3ST $^{\mathrm{C}}$ & BF2ST-BF3ST & Breed $^{\mathrm{d}}$ \\
\hline $0.75(0.02)$ & $0.67(0.02)$ & $0.77(0.02)$ & LW \\
$0.75(0.03)$ & $0.73(0.04)$ & $0.81(0.02)$ & LR \\
$0.90(0.06)$ & $0.92(0.04)$ & $0.98(0.02)$ & MLW \\
\hline
\end{tabular}

${ }^{\mathrm{a}}$ Rückenspeckdicke am Achsel (Stationstest); ${ }^{\mathrm{b}}$ Rückenspeckdicke am Rückenmittel (Stationstest); ${ }^{\mathrm{C}}$ Rückenspeckdicke am Kotelett (Stationstest); ${ }^{\mathrm{d}}$ Rasse

Concerning the backfat depth measured at the same regions (shoulder, mid-back, loin) in field and station tests one can consider the BFFT-BFST pairs as identical traits if genetic correlation among them is close to unity. It can be seen (Table 6.) that in our study they ranged between low and moderately high which indicates the existence of genotype environment interaction. CRUMP et al. (1997) received high (0.81-1.0) genetic correlations for BF between different sexes therefore in their case the genotype environment interactions were negligible. CAMERON (1993) on the other hand investigated the effect of the feeding regime (ad libitum vs. scale feeding) from the same aspect. The genetic correlation coefficients were definitely less than unity in case of $\mathrm{BF}(0.58-0.76)$ hence the effect of the feeding regime exceeds that of the sex from the aspect of genotype environment interactions. MERKS (1989) compared the field and station tests for BF. When ultrasonic measurements were taken both in the station and field test and also the sex of the animals were identical the genetic correlation between BFFT-BFST was moderately high (0.7). On the other hand if the sex was male in the station test and female in the field test or vice versa then the received genetic correlations were lower $(0.50-0.66)$ which indicates that the test environment together with sex effect caused a more pronounced genotype environment interactions than test environment alone. Finally if in the station test BF measurements were taken on carcasses rather than on live pigs using ultrasonic scanning then the genetic correlations were lowered even further $(0.29-0.75)$ which indicates that carcass backfat thickness was definitely not the same trait as the ultrasonic backfat measured on live pigs therefore ranking of boars based on the two environments might differ significantly. GROENEVELD and PESCOVICOVA (1999) and PESCOVICOVA et al. (1999) also estimated the genetic correlations between BF measured station and field tests and received relatively low values $(0.39-0.53)$ which were in good agreement with the results found in this study. 
Table 6

Genetic correlation coefficient estimates among the field and station test traits (measured at the same regions). Standard errors of estimates are given in brackets ((Genetische Korrelationen zwischen Stations- und Feldtestmerkmalen (Gleiche Messung, Standardabweichung in Klammern)

\begin{tabular}{ccc|c}
\hline BF1FT $^{\mathrm{a}}-$ BF1ST & BF3FT $^{\mathrm{e}}-$ BF3ST $^{\mathrm{f}}$ & Breedg $^{\mathrm{g}}$ \\
\hline $0.20(0.04)$ & $0.30(0.04)$ & $0.12(0.03)$ & LW \\
$0.40(0.04)$ & $0.40(0.05)$ & $0.40(0.01)$ & LR \\
$0.62(0.16)$ & $0.64(0.15)$ & $0.32(0.11)$ & MLW \\
\hline
\end{tabular}

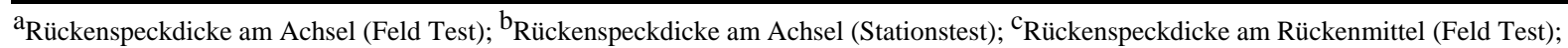
${ }^{\mathrm{d}}$ Rückenspeckdicke am Rückenmittel (Stationstest); ${ }^{\mathrm{e}}$ Rückenspeckdicke am Kotelett (Feld Test); ${ }^{\mathrm{f}}$ Rückenspeckdicke am Kotelett (Stationstest); ${ }_{\text {Rasse }}$

\section{Conclusions}

Until 1998 selection for body composition was practiced by selecting against ABFFT, which may be treated as an indirect selection (trying to increase the lean body mass). Indirect selection can be successful if the heritability of the selection criteria trait is reasonably higher than that of the trait in the breeding objective and their genetic correlation between them is high. LMPFT is one of the major composite trait of body composition and thus selection for LMPFT was also done through ABFFT in the past. Yet the heritability estimates of LMPFT proved to be higher than those of ABFFT and due to the fact that these traits were only moderately correlated (negatively) the selection for body composition using LMPFT as a selection criterion rather than ABFFT is probably more direct and will be more successful. Hence the former trait has to replace the latter in the Hungarian Pig Breeding Programme in the long run.

Looking the results in Table 6 it can be suggested that every effort should be made in order to lessen the BFFT's residual variances caused by the operators of the ultrasonic equipments by increasing the measuring discipline and care.

At the same time it might be worth considering that increasing the similarity between the station and field tests by using the same grouping system (small groups) in both environments, applying transponders and automatised feeding systems in the station test, the genetic correlations should probably be higher than those received here. Thus the ranking of boars based on the different testing methods would definitely be closer to each other than at present.

Besides, selection on body composition should make use of abattoir data more effectively than presently done as they provide much more reliable LMPFT data measured on carcasses (using automatised devices) than ultrasonic measurements of live pigs. If genetic correlations between BFFT traits and their BFST counterparts cannot be increased at least to the moderately high level then ultrasonic results perhaps should only be treated as indicative marks rather than selection criterion.

Acknowledgement

Financial support of the OTKA fund Nr. TO35151 is acknowledged.

\section{References}

BERESKIN, B.:

Genetic and phenotypic parameters for pig growth and body composition estimated by intraclass correlation and parent-offspring regression. J. Anim. Sci. 64 (1987), 1619-1629

BIDANEL, J.P.; DUCOS, A.:

Genetic correlations between test station and on-farm performance traits in Large White and French Landrace pig breeds. Livest. Prod. Sci. 45 (1996), 55-62 
CAMERON, N.D.:

Methologies for estimation of genotype with environment interaction. Livest. Prod. Sci. 35 (1993), 237249

CRUMP, R.E.; HALEY, C.S.; THOMPSON, R.; MERCER, J.:

Individual animal model of genetic parameters for performance test traits of male and female Landrace pigs tested in a commercial nucleus herd. Anim. Sci. 65 (1997), 275-283

CLUTTER, A.C.; BRASCAMP, E.W.:

Performance traits. In: The Genetics of the pig. (ed. ROTHSCHILD, M. F.; RUVINSKY, A.) CAB International, Wallingford, Oxon, UK. (1998), 435

CSATÓ, L.; FARAGÓ, I.; FARKAS, J.:

Body composition estimation of the Hungarian pigs in relation to their field test (in Hung.). Vágóállat és Hústermelés. 3 (1990), 33-37

DIXON, W.J.; BROWN, M.B.; ENGELMAN, L.; HILL, M.A.; JENNRICH, R.I.: BMDP Statistical Software Manual. University of California Press, Berkeley (1988)

DUCOS, A.:

Parametres génétiques des caracteres de production chez le porc. Mise au point bibliographique.

EISEN, E.J.: Techni-porc 17 (1994), 35-67

Selection experiments for body composition in mice and rats: a review. Livest. Prod. Sci. 23 (1989), 1732

FALCONER, D.S.:

The problem of environment and selection. The American Naturalist. 86 (1952), 293-298

GROENEVELD, E.:

PEST Users' Manual. Institute of Animal Husbandry and Animal Behaviour Federal Research Centre, Neustadt. (1990), 1-80

GROENEVELD, E.:

VCE4 Users' Guide. Institute of Animal Husbandry and Animal Behaviour Federal Research Centre, Neustadt. (1998), 1-61

GROENEVELD, E.; PESCOVICOVÁ, D.:

Simultaneous estimation of the covariance structure of field and station test traits in Slovakian pig populations. Czech J. Anim. Sci., 44 (1999), 145-150

GROENEVELD, E.; CSATÓ, L.; FARKAS, J.; RADNÓCZI, L.:

Joint genetic evaluation of field and station test in the Hungarian Large White and Landrace populations. Arch. Tierz., Dummerstorf 39 (1996), 513-531

GROENEVELD, E.; WOLF, J.; WOLFOVA, M.; JELINKOVA, V.; VECEROVA, D.:

Estimation of genetic parameters for Czech pig breeds using a multitrait animal model. Züchtungskunde 70 (1998), 96-107

HOVENIER, R.; KANIS, E.; VAN ASSELDONK, TH.; WESTERINK, N. G.:

Genetic parameters of pig meat quality traits in a halothane negative population. Livest. Prod. Sci. 32 (1992), 309-321

JOHNSON, Z.B.; CHEWNING, J.J.; NUGENT, R.A.:

Genetic parameters for production traits and measures of residual feed intake in Large White swine. J. Anim. Sci. 77 (1999), 1679-1685

KNAPP, P.; WILLAM, A.; SÖLKNER, J.:

Genetic parameters for lean meat content and quality traits in different pig breeds. Livest. Prod. Sci. 52 (1997), 69-73

MERKS, J.W.M.:

Genotype $\times$ environment interactions in pig breeding programmes. III. Environmental effects and genetic parameters in on-farm test results. Livest. Prod. Sci. 18 (1988), 129-140

MERKS, J.W.M.:

Genotype $\times$ environment interactions in pig breeding programmes. VI. Genetic relations between performances in central test, on-farm test and commercial fattening. Livest. Prod. Sci. 22 (1989), 325339

MORUPPA, S.M.; HILL, W.G.; SINETT-SMITH, P.A.:

Effect of Selection for growth, body composition and food intake in mice: utilization of increased energy intake by "cafeteria" feeding. Livest. Prod. Sci. 24 (1990), 259-271

MRODE, R.A.

Linear models for the Prediction of Animal Breeding Values. CAB International, Wallingford, Oxon, UK. (1996), 38

PESCOVICOVÁ, D.; WOLF. J.; GROENEVELD, E.; HETÉNYI, L.:

Simultaneous estimation of the covariance structure for production and reproduction traits in pigs. $50^{\text {th }}$ Annual Meeting of the EAAP Zürich, Switzerland, $22^{\text {nd }}-26^{\text {th }}$ August. (1999) Session: G2.10. 
SELLIER, P.:

Meat and carcass traits. In: The Genetics of the pig. (ed. ROTHSCHILD, M. F.; RUVINSKY, A.) CAB International, Wallingford, Oxon, UK. (1998), 466

STEWART, T.S.; SCHINKEL, A.P.:

Genetic parameters for swine growth and carcass traits. In: YOUNG, L.D. (ed.) Genetics of Swine. USA-ARS, Clay Center, Nebraska, (1989), 77-79

SZABÓ, Z.; FERENC, G.; GELEI, I.:

The use of ultrasonic grading in the formation of swine population of desired quality (in Hung.).

Állattenyésztés. 4 (1973), 349-364

TRAN, A.T.; WITTMANN, M.; LAKY, GY.:

Estimation of genetical parameters in on-farm performance testing of pigs (in Hung.). Állattenyésztés és Takarmányozás. 42 (1993), 235-246

VÁRADI, G.; BARTOS, A.; POZSGAI, É.:

The inheritance of the significant quantitative characteristics of Hungarian Large White and Duroc pigs (in Hung.). Állattenyésztés és Takarmányozás. 46 (1997), 227-236

WILSON, D.E.:

Application of ultrasound for genetic improvement. J. Anim. Sci. 70 (1992), 973-983

WOLF, J.; HORACKOVÁ, S.; GROENEVELD, E.; PESCOVICOVÁ, D.:

Estimation of genetic parameters for sire pig breeds using purebred and crossbred information. Czech J. Anim. Sci., 45 (2000), 525-532

WOLF, J.; HORACKOVÁ, S.; WOLFOVA, M.:

Genetic parameters for the Black Pied Prestice breed: comparison of different multi-trait animal models.

Czech J. Anim. Sci., 46 (2001), 165-171

Received: 2002-01-09

Accepted: 2002-07-02

Autor's addresses

Dr. LÁSZLÓ CSATÓ C.Sc., Dr. ISTVÁN NAGY*Ph.D., JÁNOS FARKAS

University of Kaposvár

Faculty of Animal Science

Guba Sándor str. 40.

Kaposvár

H-7400

Hungary

Dr. LÁSZLÓ RADNÓCZI MSc.

National Institute for Agricultural Quality Control

Keleti Károly str. 24.

Budapest

H-1024

Hungary

*Corresponding author 